\title{
Electronic Banking Services in Nigeria: Some Determinants and Opportunities for Households' Financial Inclusion
}

\author{
Isaac B. Oluwatayo \\ School of Agricultural and Environmental Sciences, University of Limpopo, South Africa \\ isaac.oluwatayo@ul.ac.za
}

\begin{abstract}
Economic transactions in many of the countries in Africa are still largely cash-based and many of these transactions are costly, inefficient, time consuming and sometimes risky because of the security situation in most countries in the continent. In fact, finality of payment is not always guaranteed because of potential counterfeits and the lack of financial discipline when cheques or other paper-based means of payment are used. The introduction of electronic banking services into the Nigerian banking sector has brought some respite considering the number of people now using electronic platforms such as the Automated Teller Machines (ATM), mobile phones, internet and bank websites instead of the conventional over the counter method used by most people. The result presented in here is based on secondary data consisting of 6002 respondents collected by The Financial Inclusion Insights Program, InterMedia. A descriptive analysis of data showed that the North-central (35\%) and South-west (33\%) geopolitical zones of the country had the highest as over one-third of the residents harnessed internet as the platform for their banking services. Meanwhile on the determinants of using electronic banking services, the result of the tobit model employed revealed age, gender, education status, and ownership of mobile phones as positive enablers and poverty status, distance to banking services and marital status as hiccups to using electronic banking services. The study therefore recommends welfare enhancement through provision of infrastructural facilities to ease access banking services, Also capacity building of respondents through education should be intensified since most of the people using these electronic platforms are those with a minimum of secondary education.
\end{abstract}

Keywords: Determinants, Mobile banking, ICT, Financial inclusion, Nigeria, Welfare

\section{Introduction}

The important role that banks play in the growth of any country cannot be overemphasised and financial inclusion has been described as one of the key pivots of economic development (Cheston et al., 2016). Electronic banking on the other hand is a service that uses electronic communication platform (Keating, 1996) and this can be categorised on the basis of the kind of instruments employed. Examples include the use of telephone connection, mobile phones, internet, personal computers as means of payment (bank cards) and other self-service techniques (Muhammad, 1997). Electronic banking therefore, which is an advancement in the application of Information and Communication Technology (ICT) in banking services uses the internet as the delivery platform to conduct banking activities such as transferring funds, paying bills, viewing and checking savings, account balances, paying mortgages and purchasing financial instruments and certificates of deposits (Mohammed et al., 2009). According to Christopher et al. (2006), electronic banking now provides opportunity for countries with underdeveloped financial systems to leapfrog developmental stages. Customers in most countries can now access services more easily from banks abroad through wireless communication systems, which are developing more rapidly than traditional "wired" communication networks. Also, electronic banking has become an important channel for banks to sell their products and services and is now perceived to be a necessity in order to stay profitable and successful.

Meanwhile it is estimated that more than half the world's adults do not have a bank account, and nearly 3 out of 4 adults in developing and middle income countries don't have bank accounts (Kendall, Mylenko, and Ponce, 2009). According to CGAP (2010), around 50 percent of households do not have access to banking services globally. In Africa, for instance, Efam (2008) reported that majority of the African population has no access to banking services, with only $20 \%$ of African families having bank accounts. Moreover, 90 percent of the 2.5 billion people living on less than $\$ 2$ /day in the developing world do not have an account with over 2.7 billion people in developing countries having no access to basic formal financial services, such as savings and checking accounts (IFC, 2011). The limited access to financial services in the continent emanates particularly from poor infrastructure, physico-geographical isolation or inaccessibility, financial illiteracy, all of which 
result into excessively high transaction cost of providing banking services. As indicated by Financial Access (2010), sub-Saharan Africa (SSA) has the lowest deposit institution penetration globally standing at an average of $16.6 \%$ compared to $63.5 \%$ in developed countries amounting to a penetration rate of about 166 banks per 1,000 adults for the SSA region. The scenario depicted above is not different from what obtains in Nigeria, where more than 30 million people are unbanked (Agbaje, 2011) partly because of inadequate and low quality infrastructure (Okpi, 2012; Oluwatayo, 2014). Financial exclusion is widespread in Nigeria especially among those residing in the rural areas. In fact, the bulk of the cash transactions and money in the country are outside the banking system thus making the issue of financial exclusion a grave challenge (Kama and Adigun, 2013).

Although the rising role of financial inclusion as a catalyst for economic growth and development is no more news especially in this age of technology revolution (mobile phones in particular), a sizeable number of Nigerians are still very apprehensive of the challenges and risks inherent in this new way of doing business that has enveloped the banking sector in the country. Added to this debacle is the rising wave of internet scam in the country and that of cyber insecurity worldwide. However, considering the intensity and volume of cashbased transactions occurring in every sector of the Nigerian economy vis-à- vis the cash-related fraud and internet scam in the country, (electronic banking will no doubt have serious implications for inclusiveness, ease of doing business, poverty reduction and employment generation especially among the poor and disadvantaged segment of the society. The Central Bank of Nigeria (CBN) in January 2012 introduced the cashless policy (a form of electronic banking) to reduce the volume of cash used for business transactions and thereby reduce cash handling costs by banks amongst other objectives (Odumeru, 2013). Electronic banking is known to engender competition among banks and made it possible for customers to compare banks' services and products, and allow banks and firms to penetrate new markets and thus expand opportunities for the poor especially in terms of their geographical reach (Schaechter, 2002; Olanipekun et al., 2013). Other benefits of electronic banking according to Olanipekun et al. (2013) are the possibility of reduction in cash-related corruption, cash-related armed robbery and increased attraction of more foreign investment which could enhance job creation.

From this standpoint, it is very clear that a good, efficient and inclusive financial services remains an important tool in the toolkit for poverty reduction (UNDP, 2010). It therefore becomes imperative to examine some of the determinants of using electronic banking services in Nigeria with the aim of providing answers to a number of questions which are highlighted below:

- What are the socioeconomic/demographic characteristics of respondents in Nigeria?

- What are the different banking facilities/platforms available and accessible to these respondents?

- Are there gender, educational and regional differences in the use of different banking platforms/facilities available in Nigeria?

- What are the determinants of using electronic banking services in the study area?

- What are the challenges of using these services?

\section{Literature Review}

There is no gainsaying the fact that many governments in a number of countries globally have made savings accounts widely available, but to make payments and transfer funds, the poor must often depend on costly and unreliable informal financial services. Meanwhile, low levels of financial inclusion represent an obstacle to economic development. This lack of access is due to various barriers that can be related to physical access, affordability and eligibility (Beck, Demirgüç-Kunt and Martinez Peria, 2008). In terms of physical access, customers may have to visit remote bank headquarters to open the account, instead of local bank branch offices. They could also face affordability problems as the minimum balances and fees may be too high. Again, the demands in terms of documentation to open a bank account or necessity to have a job in the formal sector can be perceived as eligibility barriers. Unfortunately, due to a dearth in the availability of formal financial services, many people in rural area are forced to resort to the informal sector in order to save. According to Aportela (1999) in his study on micro savings programs in Mexico, he showed how financial inclusion of low income households traditionally excluded from the formal markets, were better able to smooth their consumption when credit was relatively scarce. Karlan, Ashraf and Yin (2007) found that the use of financial products had an important effect on the empowerment of female participants, via 
an increase in their decision making capacity within the home. This is further attested to by Dupas and Robinson (2010) who also found that bank account had a substantially positive impact on poor women of Kenya. The women surveyed in the study had higher levels of savings and investment, when given a bank account. Thus, new technologies and new business models are opening new methods of retail payments, as well as bill payments and transfers of funds among people and businesses.

Meanwhile, accessing banking services in Nigeria was a big challenge especially before the recent wave of technological revolution that has enveloped the banking industry in the country. In a research conducted in Nigeria by Echekoba and Ezu (2012), it was observed that $68.2 \%$ of the respondents complained about long queues in the bank, 28.9\% complained of bad attitude of teller officers (cashiers) while $2.90 \%$ complained of long distance of bank locations to their home or work places. However, Yaqub et al. (2013) highlighted the challenges of cashless policy (a form of electronic banking services) in the country by asserting that, accompany the numerous benefits are some challenges even in the developed world. One of the setbacks identified is behavioural constraints which was premised on the fact that Nigeria is cashbased; people are accustomed to using cash for most of their transactions. They also observed that some banks in Nigeria are very conservative; they use very few innovative products and marketing techniques. The security issue is another major challenge, the low level of internet penetration and poorly developed telecommunication systems can impede smooth development and improvement in e-payments and ecommerce. It is against this backdrop that the study examines some determinants of using electronic banking services with the overall aim of unravelling its implications on households' financial inclusion in the country.

\section{Methodology}

Study Area, Data Sources and Types: The study area is Nigeria. Nigeria is one of the countries in subSaharan Africa with a population of over 160 million inhabitants (NPC, 2010). The country is made up 36 States and the Federal Capital Territory (FCT), Abuja. Nigeria is divided into six geopolitical regions - Northcentral (NC), North-west (NW), North-east (NE), South-west (SW), South-east (SE) and South-south (SS) for ease of administration. Secondary data with a sample size of 6002 collected by The Financial Inclusion Insights Program, InterMedia, covering all the 36 states of the federation and FCT were used in this study. Information contained in the dataset include socioeconomic variables, ownership of mobile phones, ownership of sim cards, types of network service providers, types of transaction and the use into which the mobile phone is put, patronage of different mobile network operators, challenges and constraints faced in accessing banking services in Nigeria etc.

Analytical Techniques: A number of analytical tools were employed in analysing the data used in this study. While descriptive statistics such as tables, frequencies, percentages and pie charts were employed to analyse and describe respondents' socioeconomic characteristics, cross-tabulation analysis was performed to ascertain the relationship between some of the socioeconomic variables and respondents' use or patronage of electronic banking services in the study area. Also, a tobit model regression (Amemiya, 1984; Cong, 2000) was employed to examine the determinants of using electronic banking services in the study area. Tobit model was used because the dependent variable is an index (ratio). The form of the tobit model used is specified as:

$$
\begin{aligned}
\mathrm{y}_{\mathrm{i}}=\left\{\begin{array}{l}
y i^{*}{ }^{*} \\
{ }^{2}
\end{array} \text { if } \begin{array}{l}
y_{i}^{*}=>0 \\
y_{i}^{*}=\leq 0
\end{array}\right. \\
\text { Where } \mathrm{yi}=\beta X i+\varepsilon_{i}
\end{aligned}
$$

and $\mathrm{X}_{\mathrm{i}}=$ explanatory variables

$\beta=$ parameters specifying relationship between $\mathrm{x}$ and $\mathrm{y}$

$\varepsilon_{i}=$ error term

$\mathrm{Y}=\mathrm{An}$ index of use of the different electronic banking platforms is generated as follows:

$\mathrm{Y}=$ Number of Electronic Banking Services Harnessed or Used by each Respondent

Total Number of Banking Services Available in the Study Area

The banking services considered include; over the counter; ATM; bank website; mobile application; over the counter in retail stores; door-to door and others. 
The explanatory variables are;

$\mathrm{X} 1=$ age (years); $\mathrm{X} 2=$ gender; $\mathrm{X} 3=$ marital status (married $=1$, others $=0$ ); $\mathrm{X} 4=$ formal education (yes $=1$, no = 0); X5 = ownership of mobile phone (yes $=1$, no $=0$ ); $\mathrm{X}_{6}=$ ownership of active sim card (yes $=1$, no $=$ 0); $\mathrm{X}_{7}=$ distance covered to access banking facilities $(\mathrm{km}) ; \mathrm{X}_{8}=$ location (rural $=1$, urban $=0$ ); $\mathrm{X} 9$ = poverty level ( poor $=1$, non-poor $=0$ ); X10 = primary job (farmer $=1$, others $=0$ ).

\section{Results and Discussion}

Socioeconomic Characteristics of Respondents: Analysis of respondents based on their socioeconomic characteristics shows that more than three-quarter of those who participated in the survey were very young with age below 45 years. Meanwhile, analysis by gender indicates that there were more males than females in the sample. Again, distribution of respondents on the basis of marital status revealed that the single and never married category had the highest percentage representing more than half $(53.7 \%)$ of the sample and over one quarter $(28.9 \%)$ were monogamous married. This generally indicated that majority of inhabitants of the country were young and still very active. Also in terms of rural-urban divide, there were more residents in the rural areas than in the cities as reflected in the survey.

Table 1: Distribution of respondents by socioeconomic characteristics

\begin{tabular}{lll}
\hline Variable & Frequency & Percent \\
\hline Age & 2054 & 34.2 \\
$15-25$ & 2332 & 38.9 \\
$25-34$ & 886 & 14.8 \\
$35-44$ & 412 & 6.9 \\
$45-54$ & 184 & 3.1 \\
$55-64$ & 134 & 2.2 \\
-65 & 3572 & 59.5 \\
Mender & 2430 & 40.5 \\
Female & & \\
Marital status & 3210 & 53.5 \\
Single and never married & 703 & 11.7 \\
Polygamous married & 1733 & 28.9 \\
Monogamous married & 72 & 1.2 \\
Divorced & 52 & 0.9 \\
Separated & 109 & 1.8 \\
Widowed & 113 & 1.9 \\
Living together/cohabiting & 1 & 0 \\
Others & 9 & 0.1 \\
No response & & \\
Location & 2505 & 41.7 \\
Urban & 3497 & 58.3 \\
Rural & 6002 & 100 \\
Total & & riguras
\end{tabular}

Author's computation from data

Figures in parenthesis are percentages

Ownership of Mobile Phone and Active Sim Cards by Gender: Respondents' distribution by gender and ownership of mobile phone revealed that there were more male mobile phone owners than female mobile phone owners and this could be attributed to the better financial condition of men than men in Nigeria. In the same vein, ownership of active sim cards indicated that there were more male owners and females with active sim cards. From the result presented in Table 2, it was evident that men were financially better off than women in the study area hence the higher number of men mobile phone owners. 
Table 2: Gender distribution of respondents by mobile phone and active sim card ownership

\begin{tabular}{llllll}
\hline \multicolumn{2}{l}{ Socioeconomic characteristics Male } & \multicolumn{2}{l}{ Female } & Total \\
\hline & Yes No & & Yes No & \\
Ownership of Mobile Phone & $3359(94.0)$ & $213(6.0)$ & $2165(89.1)$ & $265(10.9)$ & 6002 \\
Ownership of Active sim cards & $3364(94.2)$ & $208(5.8)$ & $2186(90,0)$ & $244(10.0)$ & 6002 \\
\hline
\end{tabular}

Author's computation from data

Figures in parenthesis are percentages

Gender Distribution of Respondents by Platforms/Facilities Used to Access Bank Account: The result in Table 2 showed that the most patronised platforms/facilities used by both men and women when accessing their bank account in the study area was the use of over the counter and ATM even though with more of the former $(42.1 \%)$ in the case of over the counter and (39.9\%) in the case of ATM than the latter (33.7\%) and (29.9\%) respectively. However, the use of over the counter in retail stores were more patronised by men $(1.3 \%)$ than women $(0.7 \%)$ in places where it's being used.

Table 2: Gender distribution of respondents by facilities used to access their bank account

\begin{tabular}{|c|c|c|c|c|}
\hline \multirow[t]{2}{*}{ Facility } & \multicolumn{2}{|r|}{ Male } & \multicolumn{2}{|r|}{ Female } \\
\hline & Yes & No & Yes & No \\
\hline Over the Counter & 1504 & $2068(57.9)$ & $820(33.7)$ & $1610(66.3)$ \\
\hline ATM & 1427 & $2145(60.1)$ & $726(29.9)$ & $1704(70.1)$ \\
\hline Bank Websites & $24(0.7)$ & 3548 (99.3) & $8(0.3)$ & 2422 (99.7) \\
\hline Mobile Application & $14(0.4)$ & $3558(99.6)$ & $4(0.2)$ & $2426(99.8)$ \\
\hline $\begin{array}{l}\text { Over the Counter in } \\
\text { Store }\end{array}$ & il45 (1.3) & 3527 (98.7) & $17(0.7)$ & 2413 (99.3) \\
\hline Door-to-Door Method & $12(0.3)$ & 3560 (99.7) & $13(0.5)$ & 2417 (99.5) \\
\hline Others & $0(0.0)$ & $3572(100.0)$ & $1(0.0)$ & $2429(100.0)$ \\
\hline None of these & $16(0.4)$ & 3556 (99.6) & $12(0.5)$ & 2418 (99.5) \\
\hline
\end{tabular}

Author's computation from data

Figures in parenthesis are percentages

Educational Status of Respondents and Ownership of Mobile Phone and Sim Card: As shown in Table 3, it is very clear that respondents with secondary education had the higher number both in terms of ownership of mobile phone and sim card. This was closely followed by those with some secondary education and university education. However in terms of ownership of mobile phone and sim card by educational level, those with postgraduate university degree (99.4\%) and other university education had the highest. This is an indication of the earning potential of respondents since higher education enhance people's income hence the increased number of mobile phone and sim card owners. Again, those with tertiary education can better use the technology because of their educational status as some of them use it to network with colleagues in other places both within and outside the country.

Table 3: Educational distribution of respondents by ownership of mobile phone and sim card

\begin{tabular}{|c|c|c|c|c|}
\hline \multirow[t]{2}{*}{ Educational statusFrequency } & \multicolumn{2}{|c|}{ Mobile Phone Ownership } & \multicolumn{2}{|c|}{ Sim Card Ownership } \\
\hline & Yes & No & Yes & No \\
\hline formal294 & $210(71.4)$ & $84(28.6)$ & $209(71.1)$ & $85(28.9)$ \\
\hline $\begin{array}{l}\text { Primary education } 147 \\
\text { not }\end{array}$ & $118(80.3)$ & $29(19.7)$ & $119(81.0)$ & $28(19.0)$ \\
\hline $\begin{array}{l}\text { Primary education } 483 \\
\text { complete }\end{array}$ & $426(88.2)$ & $57(11.8)$ & $432(89.4)$ & $51(10.6)$ \\
\hline Some secondary 730 & $614(84.1)$ & $116(15.9)$ & $620(84.9)$ & $110(15.1)$ \\
\hline $\begin{array}{l}\text { Secondary } \\
\text { education complete }\end{array}$ & $2162(95.5)$ & $\begin{array}{c}102 \\
(4.5)\end{array}$ & $2171(95.9)$ & $92(4.1)$ \\
\hline $\begin{array}{l}\text { Some education } 91 \\
\text { vocational training }\end{array}$ & $86(95.5)$ & $\begin{array}{c}5 \\
(4.5)\end{array}$ & $\begin{array}{l}86 \\
(94.5)\end{array}$ & $5(5.5)$ \\
\hline
\end{tabular}




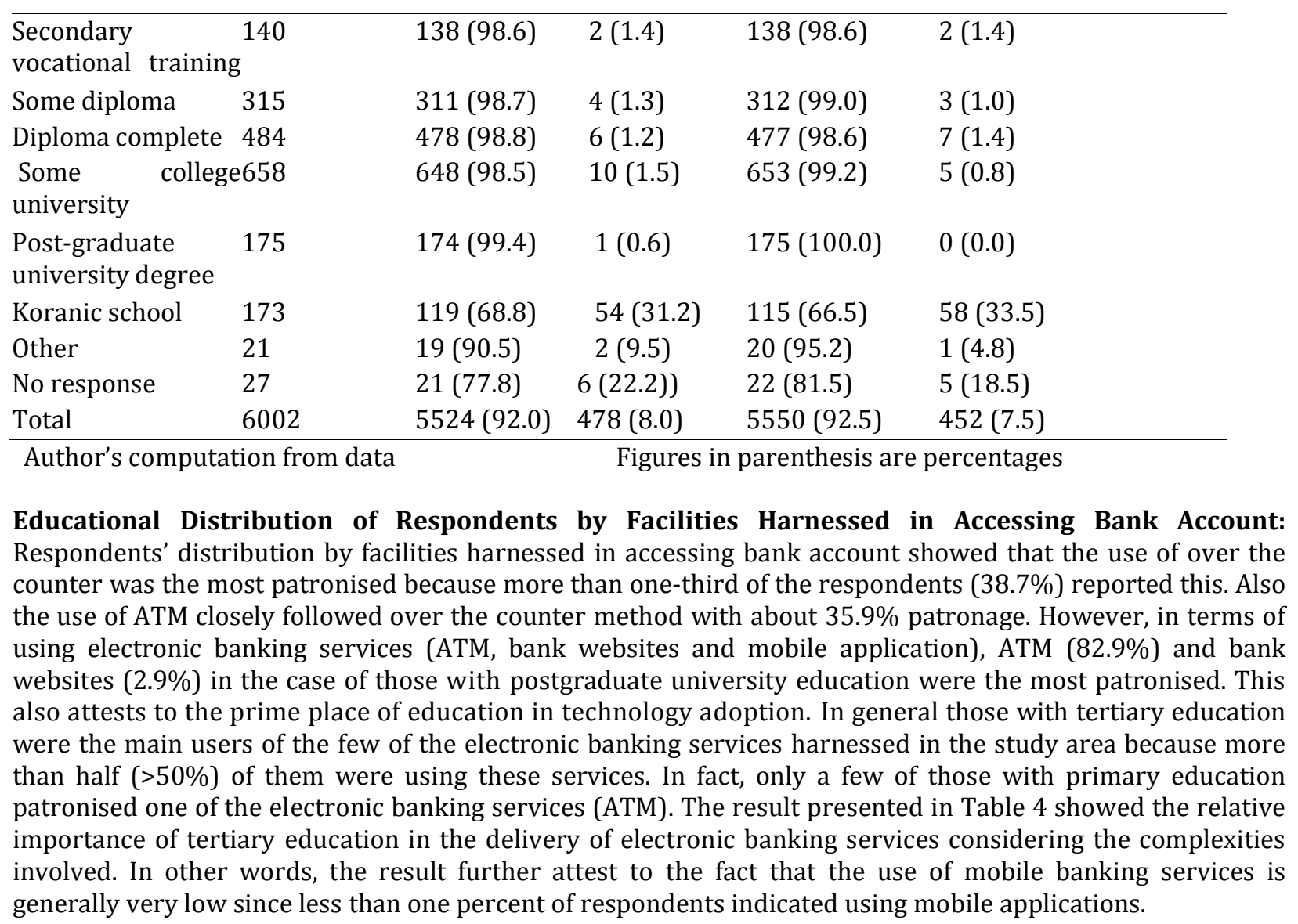

Table 4: Educational distribution of respondents by facilities harnessed in accessing bank account

\begin{tabular}{lllllllll}
\hline $\begin{array}{l}\text { Educational } \\
\text { Level }\end{array}$ & $\begin{array}{l}\text { Over theATM } \\
\text { counter }\end{array}$ & & $\begin{array}{l}\text { Bank } \\
\text { website }\end{array}$ & $\begin{array}{l}\text { Mobile } \\
\text { application }\end{array}$ & $\begin{array}{l}\text { Over the Door } \\
\text { counter door } \\
\text { in retail } \\
\text { stores }\end{array}$ & to Others & $\begin{array}{l}\text { one of } \\
\text { these }\end{array}$ \\
\hline No formal & 20 & 3 & 0 & 0 & 0 & 0 & 0 & 0 \\
education & $(6.8)$ & $(4.4)$ & $(0.0)$ & $(0.0)$ & $(0.0)$ & $(0.0)$ & $(0.0)$ & $(0.0)$ \\
Primary & 14 & 9 & 0 & 0 & 0 & 0 & 0 & 0 \\
not complete & $(9.5)$ & $(6.1)$ & $(0.0)$ & $(0.0)$ & $(0.0)$ & $(0.0)$ & $(0.0)$ & $(0.0)$ \\
Primary & 91 & 57 & 1 & 0 & 0 & 0 & 0 & 1 \\
complete & $(18.8)$ & $(11.8)$ & $(0.2)$ & $(0.0)$ & $(0.0)$ & $(0.0)$ & $(0.0)$ & $(0.0)$ \\
Some secondary & 120 & 99 & 2 & 0 & 1 & 1 & 0 & 1 \\
& $(16.4)$ & $(13.6)$ & $(0.3)$ & $(0.0)$ & $(0.1)$ & $(0.1)$ & $(0.0)$ & $(0.0)$ \\
Secondary & 825 & 730 & 8 & 2 & 18 & 15 & 1 & 16 \\
education & $(36.4)$ & $(32.2)$ & $(0.4)$ & $(0.1)$ & $(0.8)$ & $(0.7)$ & $(0.0)$ & $(0.7)$ \\
Some education & 38 & 30 & 0 & 0 & 2 & 0 & 0 & 0 \\
vocational & $(41.8)$ & $(33.0)$ & $(0.0)$ & $(0.0)$ & $(2.2)$ & $(0.0)$ & $(0.0)$ & $(0.0)$ \\
Secondary & $66(47.1)$ & 52 & 0 & 1 & 2 & 1 & 0 & 0 \\
vocational & & $(37.1)$ & $(0.0)$ & $(0.7)$ & $(1.4)$ & $(0.7)$ & $(0.0)$ & $(0.0)$ \\
complete & & & & & & & & \\
Somediploma & 188 & 187 & 1 & 0 & 5 & 0 & 0 & 2 \\
& $(59.7)$ & $(59.4)$ & $(0.3)$ & $(0.0)$ & $(1.6)$ & $(0.0)$ & $(0.0)$ & $(0.6)$ \\
Diploma & 318 & 319 & 5 & 5 & 12 & 4 & 0 & 3 \\
\hline
\end{tabular}


Journal of Economics and Behavioral Studies (ISSN: 2220-6140)

Vol. 9, No. 4, pp. 38-48, August 2017

\begin{tabular}{lllllllll}
\hline complete & $(65.7)$ & $(65.9)$ & $(1,0)$ & $(1.0)$ & $(2.5)$ & $(0.8)$ & $(0.0)$ & $(0.6)$ \\
Some college & 468 & 486 & 10 & 5 & 14 & 2 & 0 & 4 \\
university & $(71.1)$ & $(73.9)$ & $(1.5)$ & $(0.8)$ & $(2.1)$ & $(0.3)$ & $(0.0)$ & $(0.6)$ \\
Post-graduate & 143 & 145 & 5 & 5 & 8 & 1 & 0 & 0 \\
university & $(81.7)$ & $(82.9)$ & $(2.9)$ & $(0.0)$ & $(4.6)$ & $(0.6)$ & $(0.0)$ & $(0.0)$ \\
Koranic school & $12(6.9)$ & $7(4.0)$ & $0(0.0)$ & $0(0.0)$ & $0(0.0)$ & $0(0.0)$ & $0(0.0)$ & $1(0.6)$ \\
Other & 14 & 14 & 0 & 0 & 0 & 1 & 0 & 0 \\
& $(66.7)$ & $(66.7)$ & $(0.0)$ & $(0.0)$ & $(0.0)$ & $(4.8)$ & $(0.0)$ & $(0.0)$ \\
No response & 7 & $5(18.5)$ & 0 & 0 & 0 & 0 & 0 & 0 \\
& $(10.5)$ & & $(0.0)$ & $(0.0)$ & $(0.0)$ & $(0.0)$ & $(0.0)$ & $(0.0)$ \\
Total & $\mathbf{2 3 2 4}$ & $\mathbf{2 1 5 3}$ & $\mathbf{3 2}$ & $\mathbf{1 8}$ & $\mathbf{6 2}$ & $\mathbf{2 5}$ & $\mathbf{1}$ & $\mathbf{2 8}$ \\
& $\mathbf{( 3 8 . 7 )}$ & $\mathbf{( 3 5 . 9 )}$ & $\mathbf{( 0 . 5 )}$ & $\mathbf{( 0 . 3 )}$ & $\mathbf{( 1 . 0 )}$ & $\mathbf{( 0 . 4 )}$ & $\mathbf{( 0 . 0 )}$ & $\mathbf{( 0 . 5 )}$ \\
\hline
\end{tabular}

Author's computation from data Figures in parenthesis are percentages

Ownership of Mobile Phones Based on Geo-political Region: As revealed in Table 5, the North-west region of Nigeria had the largest number of people with mobile phones and this was closely followed by the Southwest region. The region with the lowest number of people with mobile phone was the North-east and this is more or less a reflection of the financial capability (poverty status) and level of education of people in the different region of the country. However, distribution of respondents within a region in terms of those having mobile phones or not showed that the South-east had the highest with about $96.9 \%$. This was closely followed by the North-central and South-west regions with $96.3 \%$ and $96.1 \%$ respectively. The region whose inhabitants had the lowest number of people with mobile phones was North-west region with about $82.0 \%$.

Table 5: Regional distribution of respondents by ownership of mobile phones

\begin{tabular}{llll}
\hline Region & Yes & No & Total \\
\hline North-central & $901(96.3)$ & $35(3.7)$ & $\mathbf{9 3 6}$ \\
North-west & $400(93.5)$ & $28(6.5)$ & $\mathbf{4 2 8}$ \\
North-east & $1351(82.0)$ & $296(18.0)$ & $\mathbf{1 6 4 7}$ \\
South-west & $1223(96.1)$ & $49(3.9)$ & $\mathbf{1 2 7 2}$ \\
South-east & $730(96.9)$ & $23(3.1)$ & $\mathbf{7 5 3}$ \\
South-south & $919(95.1)$ & $47(4.9)$ & $\mathbf{9 6 6}$ \\
& 5524 & 478 & 6002 \\
Total & $(92.0)$ & $(8.0)$ & 100.0
\end{tabular}

Author's computation from data

Figures in parenthesis are percentages 
Journal of Economics and Behavioral Studies (ISSN: 2220-6140)

Vol. 9, No. 4, pp. 38-48, August 2017

Table 6: Distribution of respondents by use of mobile phone for internet and financial transactions

\begin{tabular}{|c|c|c|c|c|c|c|}
\hline \multirow[t]{2}{*}{ Region } & \multirow{2}{*}{$\begin{array}{l}\text { Internet } \\
\text { Yes }\end{array}$} & & \multicolumn{3}{|c|}{ Financial transaction } & \multirow[t]{2}{*}{ Total } \\
\hline & & & No & Yes & No & \\
\hline $\begin{array}{l}\text { North- } \\
\text { central }\end{array}$ & $\begin{array}{l}329 \\
(35.1)\end{array}$ & & $\begin{array}{l}607 \\
(64.9)\end{array}$ & $\begin{array}{ll}28 & \\
& (3.0)\end{array}$ & $\begin{array}{l}908 \\
(97.0)\end{array}$ & $\begin{array}{l}936 \\
100.0\end{array}$ \\
\hline North-wes & $\begin{array}{l}\mathrm{t} 111 \\
(25.9)\end{array}$ & $\begin{array}{c}317 \\
(74.1)\end{array}$ & & $\begin{array}{ll}20 & \\
& (4.7)\end{array}$ & $\begin{array}{l}408 \\
(95.3)\end{array}$ & $\begin{array}{l}428 \\
100.0\end{array}$ \\
\hline North-east & $\begin{array}{l}322 \\
(20.2)\end{array}$ & & $\begin{array}{l}1315 \\
(78.8)\end{array}$ & $\begin{array}{ll}42 & \\
(2.6)\end{array}$ & $\begin{array}{l}1605 \\
(97.4)\end{array}$ & $\begin{array}{l}1647 \\
100.0\end{array}$ \\
\hline South-wes & $\begin{array}{l}t 421 \\
(33.1)\end{array}$ & $\begin{array}{l}851 \\
(66.9)\end{array}$ & & $\begin{array}{ll}51 & \\
& (4.0)\end{array}$ & $\begin{array}{l}1221 \\
(96,0)\end{array}$ & $\begin{array}{l}1272 \\
100.0\end{array}$ \\
\hline South-east & $\begin{array}{l}278 \\
(36.9)\end{array}$ & $\begin{array}{l}475 \\
(63.1)\end{array}$ & & $(6.1)$ & $\begin{array}{l}707 \\
(93.9)\end{array}$ & $\begin{array}{l}753 \\
100.0\end{array}$ \\
\hline $\begin{array}{l}\text { South- } \\
\text { south }\end{array}$ & $\begin{array}{l}355 \\
(36.7)\end{array}$ & & $\begin{array}{l}611 \\
(63.3)\end{array}$ & (3.3) & $\begin{array}{l}934 \\
(96.7)\end{array}$ & $\begin{array}{l}966 \\
100.0\end{array}$ \\
\hline Total & $\begin{array}{l}1826 \\
(30.4)\end{array}$ & & $\begin{array}{l}4176 \\
(69.6)\end{array}$ & $\begin{array}{c}219 \\
(3.6)\end{array}$ & $\begin{array}{l}5783 \\
(96.4)\end{array}$ & $\begin{array}{l}6002 \\
100.0\end{array}$ \\
\hline
\end{tabular}

Author's computation from data

Figures in parenthesis are percentages

Regional Use of Mobile Phone for Internet and Financial Transaction: The result depicted in Table 6 showed that South-west region of Nigeria had the highest use of mobile phone for internet services with about one-third (33.1\%) of the respondents accessing internet through mobile phone. This is closed followed by the South- south and the North-central. The least in the category of users was the North-west region with only about one-quarter (25.9\%) accessing internet through mobile phone. As indicated earlier, education plays a pivotal role in getting financially included. Meanwhile, in terms of users within a particular region, South-east region had the highest (36.9\%) and this was followed by the South-south (36.7\%). The region with the lowest category of users accessing internet through their mobile phone was the North-east region. This could also be attributed to the low level of education in the region. However, distribution of respondents based on the use of mobile phones to make financial transactions showed that there was generally low level of use considering the number of respondents in all the regions. However, North-west and South-west had about $4.7 \%$ and $4.0 \%$ respective users with more than $95 \%$ of respondents not performing any financial transaction via their mobile phones.

Platforms/Facilities Used in Accessing a Bank Account: As shown in Table 7, it was very clear that accessing bank account over the counter and use of Automated Teller Machines (ATMs) were the most patronised across the six geo-political regions of Nigeria. Other means of accessing bank account in Nigeria recorded very low usage since all the region had less than one percent patronage. Meanwhile, there seems to be increased use of ATM instead of the usual over the counter platform and this is an indication of improvement in the use of electronic banking facilities and this largely due to the recently introduced cashless policy in the country. 
Table 7: Regional distribution of respondents by platforms/facilities used in accessing Bank account

\begin{tabular}{|c|c|c|c|c|c|c|c|}
\hline Region & Response & NC & NE & NW & SW & SE & SS \\
\hline Over the Counter & Yes No & $\begin{array}{l}439 \\
(53.1) \\
497 \\
(46.9)\end{array}$ & $\begin{array}{l}145 \\
(33.9) \\
283 \\
(66.1)\end{array}$ & $\begin{array}{l}396 \\
(24.0) \\
1251 \\
(76.0)\end{array}$ & $\begin{array}{l}607 \\
(47.7) \\
665 \\
(52.3)\end{array}$ & $\begin{array}{l}406 \\
(53.9) \\
347 \\
(46.1)\end{array}$ & $\begin{array}{l}331 \\
(38.7) \\
635 \\
(61.3)\end{array}$ \\
\hline ATM & No & $\begin{array}{l}434 \\
(46.4) \\
502 \\
(53.6)\end{array}$ & $\begin{array}{l}157 \\
(36.7) \\
271 \\
(63.3)\end{array}$ & $\begin{array}{l}378 \\
(23.0) \\
1269 \\
(77.0)\end{array}$ & $\begin{array}{l}522 \\
(41,0) \\
750 \\
(59.0)\end{array}$ & $\begin{array}{l}360 \\
(47.8) \\
393 \\
(52.2)\end{array}$ & $\begin{array}{l}302 \\
(31.3) \\
664 \\
(68.7)\end{array}$ \\
\hline Bank Websites & Yes No & $\begin{array}{l}2(0.2) \\
934 \\
(99.8)\end{array}$ & $\begin{array}{l}1(0.2) \\
427 \\
(99.8)\end{array}$ & $\begin{array}{l}6(0.4) \\
1641 \\
(99.6)\end{array}$ & $\begin{array}{l}14(1.1) \\
1258 \\
(98.9)\end{array}$ & $\begin{array}{l}4(0.5) \\
749 \\
(99.5)\end{array}$ & $\begin{array}{l}5(0.5) \\
961 \\
(99.5)\end{array}$ \\
\hline $\begin{array}{l}\text { Mobile } \\
\text { Application }\end{array}$ & $\begin{array}{l}\text { Yes } \\
\text { No }\end{array}$ & $\begin{array}{l}0(0.0) \\
936 \\
(100.0)\end{array}$ & $\begin{array}{l}0(0.0) \\
428 \\
(100.0)\end{array}$ & $\begin{array}{l}6(0.4) \\
1641 \\
(99.6)\end{array}$ & $\begin{array}{l}7(0.6) \\
1265 \\
(99.4)\end{array}$ & $\begin{array}{l}2(0.3) \\
751 \\
(99.7)\end{array}$ & $\begin{array}{l}3(0.3) \\
963 \\
(99.7)\end{array}$ \\
\hline $\begin{array}{l}\text { Over the Counter } \\
\text { in Retail Store }\end{array}$ & rYes No & $\begin{array}{l}12(1.3) \\
924 \\
(98.7)\end{array}$ & $\begin{array}{l}0(0.0) \\
428 \\
(100.0)\end{array}$ & $\begin{array}{l}15(0.9) \\
1632 \\
(99.1)\end{array}$ & $\begin{array}{l}20(1.6) \\
1252 \\
(98.4)\end{array}$ & $\begin{array}{l}12(1.6) \\
741 \\
(98.4)\end{array}$ & $\begin{array}{l}3(0.3) \\
963 \\
(99.7)\end{array}$ \\
\hline $\begin{array}{l}\text { Door-to-Door } \\
\text { Method }\end{array}$ & Yes No & $\begin{array}{l}3(0.3) \\
933 \\
(99.7)\end{array}$ & $\begin{array}{l}1(0.2) \\
427 \\
(99.8)\end{array}$ & $\begin{array}{l}2(0.1) \\
1645 \\
(99.9)\end{array}$ & $\begin{array}{l}2(0.2) \\
1270 \\
(99.8)\end{array}$ & $\begin{array}{l}13(1.7) \\
740 \\
(98.3)\end{array}$ & $\begin{array}{l}4(0.4) \\
962 \\
(99.6)\end{array}$ \\
\hline Others & Yes & $\begin{array}{l}0(0.0) \\
936 \\
(100.0)\end{array}$ & $\begin{array}{l}0(0.0) \\
428 \\
(100.0)\end{array}$ & $\begin{array}{l}0(0.0) \\
1647 \\
(100.0)\end{array}$ & $\begin{array}{l}0(0.0) \\
1272 \\
(100.0)\end{array}$ & $\begin{array}{l}1(0.1) \\
752 \\
(99.9)\end{array}$ & $\begin{array}{l}0(0.0) \\
966 \\
(100.0)\end{array}$ \\
\hline None of these & Yes No & $\begin{array}{l}6(0.6) \\
930\end{array}$ & $\begin{array}{l}6(1.4) \\
422\end{array}$ & $\begin{array}{l}3(0.2) \\
1644\end{array}$ & $\begin{array}{l}6(0.5) \\
1266\end{array}$ & $\begin{array}{l}1(0.1) \\
752\end{array}$ & $\begin{array}{l}6(0.6) \\
960(99.4)\end{array}$ \\
\hline
\end{tabular}

Author's computation from data

Figures in parenthesis are percentages

Determinants of Usage of Electronic Banking Services in Nigeria: The result of the tobit model (Table 8) employed to examine determinants of using electronic banking services in Nigeria revealed age $(\mathrm{p}<0.10)$, gender $(\mathrm{p}<0.01)$, marital status $(\mathrm{p}<0.05)$, educational status $(\mathrm{P}<0.00)$, ownership of mobile phone $(\mathrm{p}<0.05)$, distance covered $(\mathrm{p}<0.00)$, primary occupation $(\mathrm{p}<0.10)$ and poverty status $(\mathrm{p}<0.05)$ as very important. While the coefficients of age, gender, educational status were positive, those of marital status, ownership of sim card, distance covered in accessing banking services, primary occupation and poverty status were negative. In other words, as the age of respondents increases, being a man and increase in educational status had the likelihood of enhancing the use of electronic banking services. However, being married, the farther away the distance covered to get to a banking facility, being a farmer and the poorer the respondents had the likelihood of reducing the use electronic banking services in Nigeria. Therefore, having a sim card alone without a mobile phone may not necessarily provide accessibility to electronic banking services.

Table 8: Result of tobit model showing determinants of using electronic banking services

\begin{tabular}{lll}
\hline Variable & Coefficient & Marginal effect \\
\hline Age (X1) & $0.927^{*}(0.492)$ & $0.927^{*}(0.492)$ \\
Gender (X2) & $5,149^{* * *}(2.101)$ & $5,149^{* * *}(2.101)$ \\
Marital status (X3) & $-9.571^{* *}(1.889)$ & $-9.571^{* *}(1.889)$ \\
Educational status (X4) & $3.642^{* * *}(1.007)$ & $3.643^{* * *}(1.007)$
\end{tabular}




\begin{tabular}{lll}
\hline $\begin{array}{l}\text { Ownership of mobile phone1.358** }(0.644) \\
\text { (X5) }\end{array}$ & $1.358^{* *}(0.644)$ \\
Ownership of sim card (X6) & $-1.378(1.683)$ & $-1.378(1.682)$ \\
& $-3.103^{* * *}(0.967)$ & $-3.103^{* * *}(0.967)$ \\
Distance (X7) & $0.153(0.095)$ & $0.153(0.095)$ \\
Location (X8) & $-13.302^{* *}(6.291)$ & $-13.302^{* *}(6.291)$ \\
Poverty status (X9) & $-3.662^{*}(1.920)$ & $-3.662^{*}(1.920)$ \\
Primary occupation (X10) & $0.474(1.483)$ & $0.475(1.482)$ \\
Constant &
\end{tabular}

Number of observation $=6002$, Prob $>$ chi $2=0.0001$, Log likelihood $=-154,30251$

$*, * *, * *$ are coefficients significant at $10 \%, 5 \%$ and $1 \%$ respectively

Author's computation from data Figures in parenthesis are standard errors

\section{Conclusion and Recommendations}

This paper examined some determinants of using electronic banking services in Nigeria and its implications on financial inclusion of households in Nigeria. Analysis of results obtained showed that the use of electronic banking services is generally low since most people patronised the over the counter platform instead of the use of ATM, bank website, internet and mobile application. Some of the reasons identified include low level of education, especially among those in the North-east region of the country. Gender analysis of respondents' patronage of available platforms revealed that there were more males than females. However, the result of the tobit model performed to ascertain determinants of using electronic banking services in indicated educational level, ownership of mobile phone, distance to banking facilities and poverty status of respondents as very important. It is therefore concluded that even though there has been a significant improvement in the use of electronic banking devices, a lot still need to be done to bridge the gender, educational and rural- urban gap identified in the country.

Based on the findings of the study, the study recommends the following:

- Welfare enhancement through provision of infrastructural facilities to ease access and use of electronic banking services.

- Investment in capacity building through education so as to enhance the earning potential of people residing in the rural areas because they are the worst hit of this challenge

- Awareness creation and regular training of personnel to assist in educating the people so that the fears and risks entertained can be doused.

Acknowledgments: The author thanks the Financial Inclusion Insights Program, InterMedia for making their data available for this study.

\section{References}

Agbaje, S. (2011). Mobile Banking to Transform Nigeria's Economy, says GT Bank Boss. This Day Live, http://www.thisdaylive.com/articles/mobile-banking-to-transform-nigerias-economy-says-gtbank-boss/105126/, Assessed August 29, 2013.

Amemiya, T. (1984). Tobit models: A Survey. Journal of Econometrics, 24, 3-61.

Aportela, F. (1999). Effects of Financial Access on Savings by Low-Income People. Banco de México Research Department, Mexico City, Mexico.

Beck, T., Demirgüç-Kunt, A. \& Soledad Martinez Peria, M. (2008). Banking Services for Everyone? Barriers to Bank Access and Use around the World. World Bank Economic Review, 22, 397-430.

Cheston, S., Conde, T., Bykere, A. \& Rhyne, E. (2016) The Business of Financial Inclusion: Insights from Banks in Emerging Markets. Institute of International Finance (IIF), Centre for Financial Inclusion Final Report, July 2016, Washington DC, USA. 67pp. 
Cong, R. (2000). Marginal Effects of the Tobit Model. Stata Technical Bulletin 56: 27-34. Reprinted in Stata Technical Bulletin Reprints, 10, 189-197. College Station, TX: Stata Press.

Christopher, G. C., Mike, L. V. \& Amy, W. A. (2006). Logit Analysis of Electronic Banking in New Zealand. International Journal of Bank Marketing, 24(6), 360-383.

Consultative Group to Assist the Poor (CGAP). (2010). Financial Access 2010. The State of Financial Inclusion Through the Crisis. Washington D.C.: CGAP.

Dupas, P. Y. \& Robinson, J. (2010). Savings Constraints and Microenterprise Development: Evidence from a Field Experiment in Kenya. NBER Working Paper No. w14693. http://www.nber.org/papers/w14693.pdf.

Echekoba, F. N. \& Ezu, G. K. (2012). Electronic Retail Payment Systems: User Acceptability and Payment Problems in Nigeria. Arabian Journal of Business and Management Review, 5, 60 - 63.

Efam. D. (2008). Boosting Domestic Savings in Africa', Vol. 22, No. 3. To invest more, countries must tap assets now outside the banks. www.un.org/ecosocdev/geninfo/afrec.

Financial Access. (2010). Sub-Saharan Africa Factsheet, CGAP-World Bank, www.cgap.org/financialindicators.

Firdous, S. (2017). Impact of Internet Banking Service Quality on Customer Satisfaction. Journal of Internet Banking and Commerce, 22(1), 1-17

IFC. (2011). IFC Mobile Money Study, Summary Report. International Finance Corporation in Partnership with the Republic of Korea, IFC, Pennsylvania Avenue, Washington D. C., USA.

Kama, U. \& Adigun, M. (2013). Financial Inclusion in Nigeria: Issues and Challenges. Central Bank of Nigeria (CBN), Abuja Nigeria. Occasional Paper No 45, 49pp.

Karlan, D., Ashraf, N. \& Yin, W. (2007). Female Empowerment: Impact of a Commitment Savings Product in the Philippines. Centre for Global Development, Working Paper No. 106.

Keating, P. (1996). What Works and What doesn't in the World of Digital Finance. Money Magazine, 135-143. July 1996.

Kendall, Mylenko \& Ponce. (2009). Measuring Financial Access Around the World, World Bank Policy Research Working Paper 5253, World Bank.

Mohammed, S. K., Siba, S. M. \& Sreekumar, M. (2009). Service Quality Evaluation in Internet Banking: An Empirical Study in India. International Journal of Indian Culture and Business Management, 2(1), 30-46

Muhammad, T. K. (1997). Electronic Commerce and the Future of Money; Technology and You, Black Enterprise, pp. 255-259. NPC (2010) Census Report, National Population Commission, Abuja, Nigeria.

Odumeru, J. A. (2013). Going Cashless: Adoption of Mobile Banking in Nigeria. Arabian Journal of Business and Management Review (Nigerian Chapter), 1(2), 9-17.

Okpi, A. (2012). Infrastructure not Sufficient for Cashless Economy, The Punch, 8 January, 2012, Pg. 4.

Olanipekun, W. D., Brimah, A. N. \& Akanni, L. F. (2013). Integrating Cashless Economic Policy in Nigeria: Challenges and Prospects. International Journal of Business and Behavioural Sciences, 3(5), 1-8.

Oluwatayo, I. B. (2014). Techno-driven Financial Inclusion in Rural Nigeria: Challenges and Opportunities for Pro-poor Service Delivery. Banks and Bank Systems, 9(2), 72-76.

Schaechter, A. (2002) Challenges of the E-banking Revolution. Finance and Development.

United Nations Development Programme, UNDP. (2010). Human Development Report Nigeria - achieving growth with equity, UNDP.

Yaqub, J. O., Bello, H., Adenuga, I. A. \& Ogundeji, M. O. (2013). The Cashless Policy in Nigeria: Prospects and Challenges. International Journal of Humanities and Social Science, 3(3), 200-212. 